\title{
Development of Physical Distancing Detector (PDD) Integrated Smartphone to Help Reduce the Spread of Covid-19
}

\author{
Suryanti ${ }^{1, *}$ HP Paksi ${ }^{1}$ VD Wicaksono ${ }^{1}$ W Widodo ${ }^{2}$ I Sucahyo $^{2}$ \\ ${ }^{l}$ Faculty of Education, Universitas Negeri Surabaya, Surabaya, Indonesia \\ ${ }^{2}$ Faculty of Mathematics and Natural Science, Universitas Negeri Surabaya, Surabaya, Indonesia \\ *Corresponding author. Email: suryanti@unesa.ac.id
}

\begin{abstract}
The Government of Indonesia has issued rules on how to avoid covid-19 transmission, namely through various means including social distancing (SD) and physical distancing (PD), at least 1 meter. Until now to run the PD protocol based only on estimates, there has been no safe distance detection tool between humans. Therefore, the purpose of this research is to develop a safe distance detection tool in conducting a viable PD, named Pysical Distancing Detector (PDD. It consists of (a)ultrasonic sensor, (b)speaker, (c)Arduino, (d)Bluetooth, (e)battery, (f)micro. Physical Distancing Detector consists of a combination of components consisting of a lipo battery that can be recharged by the LIPO charger module. The electrical power generated by lipo batteries is used for microcontrollers (in this case used nano arduino). As for detecting the distance used by ultrasonic sensors, signals generated by ultrasonic sensors will be processed by microcontrollers. Ultrasonic sensors are mounted on the cap on the sides of the face - back and right - left of the hat. The result of this microcontroller is the sound emitted by the buzzer and the data sent by the Bluetooth module to the android gadget (HP) that has been equipped with software (applications). The results of this PPD test showed that the tool was meticulous at a "critical" distance of $1.5 \mathrm{~m}$ to $2 \mathrm{~m}$. This tool can then be utilized in various people working in offices or strategic agencies that provide services to many people, such as health care, education, public services, public order (police), banking, food needs, oil and gas fuels, economy, communication, industry, export and import, distribution, logistics, and needs.
\end{abstract}

Keywords: Physical distancing, covid-19, arduino, censor

\section{INTRODUCTION}

Around November 2019, the world was hit by a virus outbreak called Coronavirus Disease 19 or abbreviated covid19. In humans, Covid-19 causes respiratory tract infections from mild to deadly. The virus first appeared in Wuhan, one of China's cities. The intersection of news about the source of the appearance of this virus, ranging from food to poultry animals. This is because there is no clear information about the origin of the virus.

The medium of transmission suspected of being a chain of transmission from one human to another is a droplet, in the form of saliva and sneezing fluid. Transmission from man to man has been confirmed to occur [1]. In addition, the virus also sticks to solid objects for some time, it can be in a matter of hours or days depending on the density of the object and the

temperature around it. If a human accidentally touches or holds an object exposed to a virus, it can move to humans.

The medium of transmission suspected of being a chain of transmission from one human to another is a droplet, in the form of saliva and sneezing fluid. Transmission from man to man has been confirmed to occur [1]. In addition, the virus also sticks to solid objects for some time, it can be in a matter of hours or days depending on the density of the object and the temperature around it. If a human accidentally touches or holds an object exposed to a virus, it can move to humans.

Not all people exposed to Covid-19 show symptoms of pain. It depends on the stamina of the body and the immune strength that is in his body. Even in many cases someone exposed to Covid-19 shows no symptoms of pain at all. Although not sick, the human being can be a carrier for other humans. If the virus is attached to a person whose body and immune system condition is not good, then the person will be sick. Symptoms of InfkesiCovid-19 can appear within 2-14 
days after exposure to Covid-19, but most Covid-19 sufferers feel symptoms after 11-12 days [2] marked by the appearance of flu, cough, fever and shortness of breath symptoms.

To date no specific vaccine has been found to treat covid19. Therefore, the most effective way that can be done today to inhibit the spread of viruses is to minimize direct contact with humans or objects that have been exposed to Covid-19. But the problem is, we don't know who or what objects have been exposed to the virus, because every human is currently potentially a carrier of the virus (carier).

According to [3] in China with intensive control including travel restrictions will take place effective before the epidemic expands. The government has made policy according to the conditions of each region. Starting by increasing immunity (herd Immunity), maintaining social distance by not coming to the crowd (Social Distancing), right down to locking and isolating yourself (Lockdown).

But Indonesians do not all comply with the government's advice. There are still many people who continue to interact with others for various reasons. Especially for people who have a daily income. They can't last long at home without income. This is what causes the virus to rapidly spread over time.

We can't force everyone not to interact with other humans because in fact humans are social beings. Thus the most rational alternative today is to maintain a physical distance to avoid direct contact (Physical Distancing). Humans can still interact but should not come into contact. They have to keep a safe distance. Who recommends a safe distance of more than 1 meter? However, some health experts suggest keeping a distance of at least two meters from others [4]. This is measured from the distance of the liquid that is scattered from a person when sneezing.

This physical distance keeping behavior turned out not to be as easy as imagined. The main factor is because humans often forget when they have fun interacting so that they have unconsciously crossed a safe distance, or worse until they come into physical contact. With such a move, one must bear the role of a isolate that connotes negatively: power-free, lonely, boring, and so on [5].

Distance-related research has been conducted by previous researchers including conducted by [6] under the title Handsight: Hand-Mounted Device to Help The Visually Impaired Based Ultrasonic and Arduino," Journal of Technology and Computer Systems, vol. 3, no. 1, pp. 51-57, Jan. 2015. Handsight can help users to avoid obstacles that are in front and can also be used to find objects on the table or floor. Handsight consists of three main parts, namely a pair of sensors, microcontrollers and distance atuators in the form of buzzers and servos. Two HC-SR04 sensors are mounted by forming an angle of about $30 \mathrm{o}$, and serve to detect objects and measure distance. The use of two sensors is expected to provide a fairly wide reading area, since the effective reading of each sensor is about 150 for each side, with the merging tool able to read objects with a total radius of 60 degrees.

In addition, research conducted by [7] titled Design blind guides using Microcontroller-Based Ultrasonic Sensors, Scientific Magazine of Electrical Technology, [S.1.], v. 16, n. 3, p. 27 - 32, dec. 2017. Blind guide tool uses belt as the main design, so that it is more mobile. The blind guide tool uses the belt as the main design. Sensors are placed on the left, front, and right sides of the belt to detect objects that are at the sensor's reflection distance. The vibrating motor is placed on the side of the sensor to provide vibration when the ultrasonic sensor is active. The blind guide has specifications in detecting a distance of $30 \mathrm{~cm}$ on the left of the belt, $150 \mathrm{~cm}$ in front of the belt, $30 \mathrm{~cm}$ on the right of the belt and $120 \mathrm{~cm}-125 \mathrm{~cm}$ under the belt.

In addition, there are currently inventions related to android applications called Distance Meter and the like. It is used to measure distance and altitude using hp cameras. The working principle of this application is that with known focus distance and shadow distance, it will be able to determine the distance of the object. It also has drawbacks such as less precision, for example the actual distance is $1.8 \mathrm{~m}$ but the measured distance is $1.4 \mathrm{~m}$. In addition, based on user comments, this tool is not enough to make a rough patch, suitable for estimation but not yet the benchmark of the result. In addition, the above two inventions have no warning to their users.

On the basis of these conditions, researchers have the idea to create a tool that can detect a person's safe distance to others and provide information to the user of the tool so that it can take the necessary security measures. This tool is planned to be named Physical Distancing Detector which is placed inside the hat.

The tool will be designed by utilizing an ultrasonic distance sensor connected to the module, then transmitting data regarding the user's distance with others. Data is sent by Bluetooth connected to the Smartphone as the recipient of the data to provide voice/vibration messages about the safe distance. Bluetooth technology is utilized as a frequency hopping transceiver that provides real-time data communication. PDD is hidden so that others around you do not know that the user is wearing the tool. Thus social activities can run normally without anyone being disturbed.

\section{RESEARCH METHOD}

The research phase is designing prototypes and trials. The prototype design of this physical distancing detector as in Figure 1.

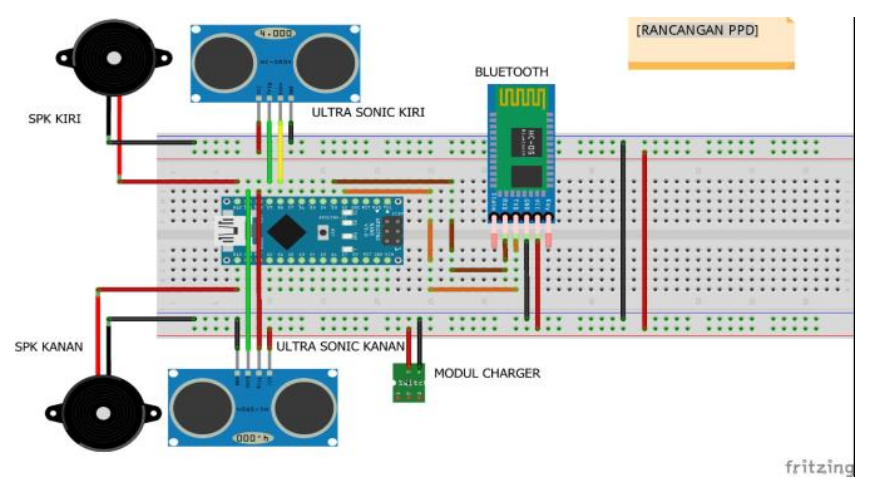

Figure 1. Prototype design

\section{This PDD component consists of}

a. Arduino UNO. Arduino is a single-board multipurpose microcontroller that can be programmed and opensource. Arduino no longer requires separate hardware (called programmers or downloaders) to load or upload new code into microcontrollers. Simply use a USB cable to start using arduino

b. Ultrasonic Sensors. is a sensor that serves to convert the magnitude of the fission into the amount of electricity and vice versa. The way this sensor works is based on the principle of the reflection of a sound wave so that it can 
be used to interpret the existence (distance) of an object with a certain frequency

c. LCD (Liquid Cristal Display) is one of the electronic components that serves as the display of a data, whether characters, letters or graphics

d. Buzzer, is an electronic component that serves to turn electrical vibrations into sound vibrations. Basically the working principle of the buzzer is almost the same as the loud speaker, so the buzzer also consists of a coil attached to the diaphragm and then the coil is flowed so that it becomes electromagnet, the coil will be drawn in or out, depending on the direction of the current and the polarity of the magnet, because the coil is mounted on the diaphragm then each coil movement will move the diaphragm back and forth so as to create vibrating air that will produce sound

e. BluetoothHC-05 module, is a wireless communication protocol that works on $2.4 \mathrm{GHz}$ radio frequencies for data exchange on mobile devices such as PDA, laptops, HP, and others.

\section{EXPERIMENT AND RESULT}

The data from this study is in the form of distance warning sensitivity data according to PDD with people, PDD distance data with a barrier between the actual distance and the distance stated on the smartphone. Analysis of the data is in the form of an error percentage analysis, and the percentage of errors at various distances.

Table 1. Warning Sensitivity Test Results on PDD Distance with People

\begin{tabular}{|c|c|c|c|c|c|c|c|c|c|l|}
\hline \multirow{2}{*}{ No } & \multicolumn{7}{|c|}{ Distance (cm) } & \multirow{2}{*}{ Description } \\
\cline { 2 - 10 } & $\mathbf{4 0}$ & $\mathbf{6 0}$ & $\mathbf{8 0}$ & $\mathbf{1 0 0}$ & $\mathbf{1 2 0}$ & $\mathbf{1 4 0}$ & $\mathbf{1 6 0}$ & $\mathbf{1 8 0}$ & $\mathbf{2 0 0}$ & \\
\hline 1 & 0 & 1 & 1 & 1 & 1 & 1 & 1 & 0 & 0 & $\begin{array}{l}\text { Stay away } \\
\text { from } \\
\text { censorship }\end{array}$ \\
\hline 2 & 0 & 1 & 1 & 1 & 1 & 1 & 1 & 0 & 0 & $\begin{array}{l}\text { Approaching } \\
\text { the sensor }\end{array}$ \\
\hline 3 & 0 & 1 & 1 & 1 & 1 & 1 & 1 & 0 & 0 & $\begin{array}{l}\text { Stay away } \\
\text { from } \\
\text { censorship }\end{array}$ \\
\hline 4 & 0 & 1 & 1 & 1 & 1 & 1 & 1 & 0 & 0 & $\begin{array}{l}\text { Approaching } \\
\text { the sensor }\end{array}$ \\
\hline 5 & 0 & 1 & 1 & 1 & 1 & 1 & 1 & 0 & 0 & $\begin{array}{l}\text { Stay away } \\
\text { from } \\
\text { censorship }\end{array}$ \\
\hline 6 & 0 & 1 & 1 & 1 & 1 & 1 & 1 & 0 & 0 & $\begin{array}{l}\text { Approaching } \\
\text { the sensor }\end{array}$ \\
\hline
\end{tabular}

Description:

$1=$ beep/vibrate

$0=$ No beeps/shakes

At a distance of $160 \mathrm{~cm}$ from the sensor there is a slightly high beep tone indicating close to a safe distance.

The data in Table 1 indicates that PDD can alert the user, in accordance with the distance generated on the PDD processor based on the results of received ultrasonic wave sensing. However, whether the distance produced by this PDD corresponds to the actual distance, a benchmarking test is performed, the result of which is shown in Table 2.
Table 2. PDD Distance Results Data with Barriers Listed on Smartphones

\begin{tabular}{|c|c|c|c|c|c|c|c|c|c|}
\hline \multirow{2}{*}{ NO } & \multicolumn{8}{|c|}{ PDD Distance to Barrier (cm) } \\
\cline { 2 - 10 } & $\mathbf{4 0}$ & $\mathbf{6 0}$ & $\mathbf{8 0}$ & $\mathbf{1 0 0}$ & $\mathbf{1 2 0}$ & $\mathbf{1 4 0}$ & $\mathbf{1 6 0}$ & $\mathbf{1 8 0}$ & $\mathbf{2 0 0}$ \\
\hline 1 & 38.1 & 57.4 & 76.4 & 94.7 & 114.8 & 135.8 & 153.4 & 173.6 & 193.8 \\
\hline 2 & 38.0 & 57.5 & 76.5 & 94.6 & 114.9 & 135.7 & 153.3 & 173.5 & 193.4 \\
\hline 3 & 37.6 & 57.6 & 76.3 & 94.6 & 114.9 & 136.1 & 152.8 & 174.0 & 192.0 \\
\hline 4 & 37.7 & 57.5 & 76.4 & 94.7 & 115.0 & 135.7 & 153.7 & 173.1 & 192.7 \\
\hline 5 & 37.7 & 57.6 & 76.4 & 94.6 & 115.3 & 136.5 & 153.6 & 173.5 & 192.9 \\
\hline 6 & 37.8 & 57.2 & 76.4 & 94.7 & 114.9 & 135.7 & 153.2 & 173.9 & 193.0 \\
\hline 7 & 37.8 & 57.6 & 76.3 & 94.5 & 115.3 & 135.2 & 153.4 & 173.2 & 193.2 \\
\hline 8 & 37.8 & 57.5 & 76.3 & 94.6 & 114.9 & 135.3 & 153.3 & 174.6 & 193.2 \\
\hline 9 & 37.7 & 57.4 & 76.2 & 94.7 & 115.3 & 136.3 & 153.3 & 173.7 & 192.8 \\
\hline 10 & 37.8 & 57.1 & 76.4 & 94.3 & 114.9 & 136.0 & 152.9 & 173.6 & 192.7 \\
\hline 11 & 37.7 & 57.5 & 76.2 & 94.5 & 114.8 & 136.8 & 153.3 & 173.6 & 193.0 \\
\hline 12 & 37.7 & 57.4 & 76.8 & 94.7 & 115.5 & 136.6 & 153.3 & 173.5 & 192.6 \\
\hline
\end{tabular}

Based on Table 2 data, it appears that there is a difference (error) between the actual distance and the distance according to pdd. Analysis of error percentage is shown in Table 3.

Table 3. Percentage of Distance Errors in Smartphone with Actual

\begin{tabular}{|c|c|c|c|c|c|c|c|c|c|}
\hline \multirow{2}{*}{ No. } & \multicolumn{9}{|c|}{ Percentage of Errors at PDD Distance with Barrier } \\
\hline & 40 & 60 & 80 & 100 & 120 & 140 & 160 & 180 & 200 \\
\hline 1 & $4.75 \%$ & $4.33 \%$ & $4.50 \%$ & $5.30 \%$ & $4.33 \%$ & $3.00 \%$ & $4.13 \%$ & $3.56 \%$ & $3.10 \%$ \\
\hline 2 & $5.00 \%$ & $4.17 \%$ & $4.38 \%$ & $5.40 \%$ & $4.25 \%$ & $3.07 \%$ & $4.19 \%$ & $3.61 \%$ & $3.30 \%$ \\
\hline 3 & $6.00 \%$ & $4.00 \%$ & $4.63 \%$ & $5.40 \%$ & $4.25 \%$ & $2.79 \%$ & $4.50 \%$ & $3.33 \%$ & $4.00 \%$ \\
\hline 4 & $5.75 \%$ & $4.17 \%$ & $4.50 \%$ & $5.30 \%$ & $4.17 \%$ & $3.07 \%$ & $3.94 \%$ & $3.83 \%$ & $3.65 \%$ \\
\hline 5 & $5.75 \%$ & $4.00 \%$ & $4.50 \%$ & $5.40 \%$ & $3.92 \%$ & $2.50 \%$ & $4.00 \%$ & $3.61 \%$ & $3.55 \%$ \\
\hline 6 & $5.50 \%$ & $4.67 \%$ & $4.50 \%$ & $5.30 \%$ & $4.25 \%$ & $3.07 \%$ & $4.25 \%$ & $3.39 \%$ & $3.50 \%$ \\
\hline 7 & $5.50 \%$ & $4.00 \%$ & $4.63 \%$ & $5.50 \%$ & $3.92 \%$ & $3.43 \%$ & $4.13 \%$ & $3.78 \%$ & $3.40 \%$ \\
\hline 8 & $5.50 \%$ & $4.17 \%$ & $4.63 \%$ & $5.40 \%$ & $4.25 \%$ & $3.36 \%$ & $4.19 \%$ & $3.00 \%$ & $3.40 \%$ \\
\hline 9 & $5.75 \%$ & $4.33 \%$ & $4.75 \%$ & $5.30 \%$ & $3.92 \%$ & $2.64 \%$ & $4.19 \%$ & $3.50 \%$ & $3.60 \%$ \\
\hline 10 & $5.50 \%$ & $4.83 \%$ & $4.50 \%$ & $5.70 \%$ & $4.25 \%$ & $2.86 \%$ & $4.44 \%$ & $3.56 \%$ & $3.65 \%$ \\
\hline 11 & $5.75 \%$ & $4.17 \%$ & $4.75 \%$ & $5.50 \%$ & $4.33 \%$ & $2.29 \%$ & $4.19 \%$ & $3.56 \%$ & $3.50 \%$ \\
\hline 12 & $5.75 \%$ & $4.33 \%$ & $4.00 \%$ & $5.30 \%$ & $3.75 \%$ & $2.43 \%$ & $4.19 \%$ & $3.61 \%$ & $3.70 \%$ \\
\hline Average & $5.54 \%$ & $4.26 \%$ & $4.52 \%$ & $5.40 \%$ & $4.13 \%$ & $2.88 \%$ & $4.19 \%$ & $3.53 \%$ & $3.53 \%$ \\
\hline Average & \multicolumn{9}{|c|}{$4.22 \%$} \\
\hline
\end{tabular}

Based on Table 3, it is obtained that overall, the average percentage of errors is below $5 \%$, which is $4.22 \%$. These results suggest this variation in PDD distance is acceptable. What's more, the position that PDD gets is closer than the actual position, so a warning is given when the actual distance is greater than the distance stated in the PDD, which is in accordance with the intent of the PDD created.

The error percentage graph at various distances is shown in Figure 2

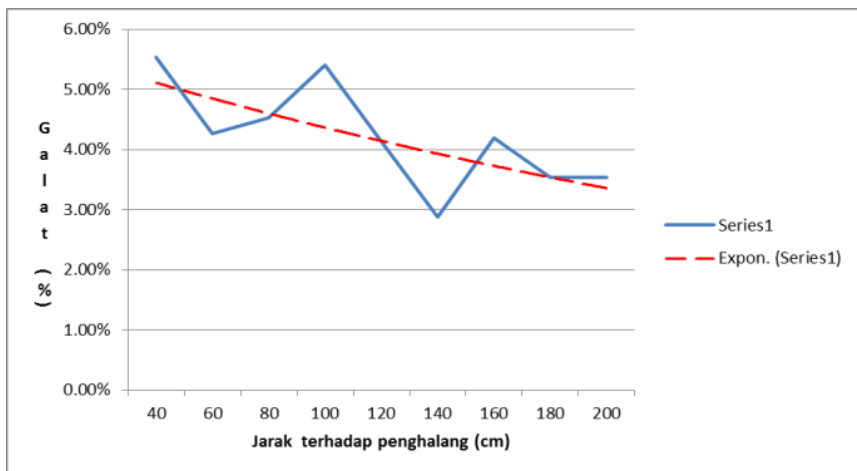

Figure 2 Tool percentage graph at various distances 
The chart trend in Figure 2 shows the further away from the barrier, the better PDD works. This is because the distance between the ultrasonic wave transmitter and the receiver becomes insignificant to the distance with the barrier. Because the PDD function warns at distances ranging from $2 \mathrm{~m}$ to below $2 \mathrm{~m}$, (with the frequency of "beeps" changing faster like parking sensors), the PDD is meticulous at a "critical" distance of $1.5 \mathrm{~m}$ to $2 \mathrm{~m}$.

\section{CONCLUSION AND FUTURE WORK}

PDD can alert the user, according to the distance generated on the PDD processor based on the results of ultrasonic wave sensing received The position obtained by PDD is closer than the actual position, so the warning is given when the actual distance is greater than the distance stated in the PDD. The results of the trial showed that PDD worked according to the objective, i.e. pdd is meticulous at a "critical" distance of $1.5 \mathrm{~m}$ to $2 \mathrm{~m}$. The results of this study are still open to follow-up research involving the public as actual users.

\section{REFERENCES}

[1] Lu, Roujian. (2020). Genomic Characterisation and Epidemiology of 2019 Novel Coronavirus: Implications for Virus Origins and Receptor Binding. Lancet, 22 Februari, 565-574.

[2] Nareza, Meva. (2020). Kenali Gejala Orang Terinfeksi Virus Corona di Minggu Pertama.. https://www.alodokter.com/kenali-gejala-orangterinfeksi-virus-corona-di-minggu-pertama.v, accessed 13 April 2020.

[3] Kraemer, M. U. G, et al. (2020)."The effect of human mobility and control measures on the COVID-19 epidemic in China. Science 10.1126/science.abb4218.

[4] Mukaromah Lu, Roujian. (2020). Genomic Characterisation and Epidemiology of 2019 Novel Coronavirus: Implications for Virus Origins and Receptor Binding. Lancet, 22 Februari, 565-574.

[5] Mona, Nailul. (2020). Konsep Isolasi dalam Jaringan Sosial untuk Meminimalisasi Efek Contagious (Kasus Penyebaran Virus Corona di Indonesia). Jurnal Sosial Humaniora Terapan, 2 (2), 117-124.

[6] S. Purnomo dkk. (2015). Handsight: Hand-Mounted Device untuk Membantu Tunanetra Berbasis Ultrasonic dan Arduino. Jurnal Teknologi dan Sistem Komputer, 3 (1). 51-57.

[7] Al Hasan, Muhammad. (2017). Rancang Bangun Pemandu Tuna Netra Menggunakan Sensor Ultrasonik Berbasis Mikrokontroler, Majalah Ilmiah Teknologi Elektro, [S.1.], 16 (3), 27 - 32. 